\title{
KNOWLEDGE ABOUT BLOOD TRANSFUSION IN A CRITICAL UNIT OF A TEACHING HOSPITAL
}

\author{
CONHECIMENTO SOBRE HEMOTRANSFUSÃO EM UNIDADE CRÍTICA DE \\ HOSPITAL DE ENSINO
}

\author{
Rafaela Dagma DUARTE ${ }^{1}$; Karla Fabiana Nunes da SILVA ${ }^{2}$; \\ Márcia Marques dos Santos FÉLIX ${ }^{3}$; Jordânia Lumênia TAVARES ${ }^{4}$; \\ Fernanda Bonato $\mathrm{ZUFFI}^{5}$; Maria Helena BARBOSA ${ }^{6}$
}

1. Enfermeira Egressa do Curso de Graduação em Enfermagem da Universidade Federal do Triângulo Mineiro (UFTM), Uberaba, MG, Brasil.rafaeladagma@hotmail.com; 2. Mestre em Atenção à Saúde, Aluna de doutorado do Programa de Pós-Graduação stricto sensu em Atenção à Saúde da UFTM, Uberaba, MG, Brasil. Professora Curso Técnico em Enfermagem, Cefores, UFTM, Uberaba, MG, Brasil; 3. Mestre em Ciências da Saúde. Aluna de doutorado do Programa de Pós-Graduação stricto sensu em Atenção à Saúde da UFTM, Uberaba, MG, Brasil; 4. Mestre em Atenção à Saúde pelo Programa de Pós-Graduação stricto sensu em Atenção à Saúde da UFTM, Uberaba, MG, Brasil; 5. Mestre em Enfermagem. Professora Assistente do Curso de Graduação em Enfermagem da UFTM, Uberaba, MG, Brasil; 6. Doutora em Enfermagem na Saúde do Adulto. Professora Associado do Departamento didático-científico de Enfermagem na Assistência Hospitalar e do Programa de Pós-Graduação stricto sensu em Atenção à Saúde da UFTM, Uberaba, MG, Brasil. mhelena331@hotmail.com

\begin{abstract}
This study aimed to evaluate the knowledge of professionals of the nursing team of an intensive care unit about blood transfusion and to identify the factors associated with such knowledge. Observational, analytical, non-experimental and cross-sectional study held in adult intensive care units of a large, public, teaching hospital located in Minas Gerais. A validated instrument of the type check list was used to collect data. Descriptive analysis, calculation of knowledge scores, $t$-tests and Pearson correlation tests were performed. The study included 64 professionals of the nursing team, among which $73.4 \%$ were nursing technicians and $85.9 \%$ were female. The average age was 37.7 years. A total of 93.8\% professionals said they had received training on blood transfusion; $76.6 \%$ said they sought information on the subject; and $100 \%$ reported to feel confident while performing the procedure. The average overall knowledge score was $52.8 \%$. Factors associated with knowledge about blood transfusion were: professional category nurse, participation in training and specific course for professional improvement, post-graduate degree, number of blood transfusions carried out per month and time working in the sector. A lack of knowledge was observed among professionals in relation to transfusion therapy. This reinforces the need to increase the opportunities to acquire skills such as training courses and continuing and permanent education for nursing professionals who work in critical care units, focusing on patient safety and quality of care.
\end{abstract}

KEYWORDS: Knowledge. Nursing team. Intensive Care Units. Blood transfusion.

\section{INTRODUCTION}

The blood and its components are used as support for treatment of several diseases and as support in transplants, chemotherapy and surgeries, thus representing essential and irreplaceable products. Although there are risks, blood transfusion is an essential part of health care, promotion and recovery (SILVA; SOMAVILLA, 2010).

Currently, transfusion activities in the country are standardized and regulated by Decree 158 of February 4, 2016, of the the Ministry of Health, and by the Collegiate Board Resolution (CBR) 34 of June 11, 2014, of the National Health Surveillance Agency (ANVISA). Both redefine the technical regulation of haemotherapic procedures, establish requirements to be met by the hemotherapy and health services that perform transfusion procedures, and recommend the need for qualification and training of professionals involved in the transfusion process (BRASIL, 2014, 2016).

The transfusion act occurs routinely in hospitals, especially in sectors in which patients are in more serious and complex situations, as for example, in intensive care units (ICU). Anemia is very common in patients hospitalized in these units and this may get worse after hospitalization and during the patient's stay. In these cases, blood transfusions are more frequently needed (CORWIN et al., 2004; COSTA FILHO et al., 2009).

The transfusion process requires skilled professionals, trained to perform this function. The monitoring of nurses is needed in all its stages, to ensure the safety of the procedure and of the patient (BARBOSA et al., 2011).

Studies carried out in Turkey, France and the United Kingdom demonstrate failures in relation to knowledge of nurses who perform blood transfusions (BAYRAKTAR; ERDIL, 2000; 
SAILLOUR-GLÉNISSON et al., 2002; SERIOUS HAZARDS OF TRANSFUSION, 2009). In Brazil, there are few studies on this topic, and therefore, there is a need for research to assess the knowledge of professionals involved in the transfusion process (SELLU; DAVIS; VICENT, 2012).

Nursing care in hemotherapy, when executed effectively and efficiently, contributes to significant reduction of risks to the patient. The knowledge and skills of professionals certainly minimize complications and risks to the patient, and guarantee the safety and quality of the transfusion process (FERREIRA et al., 2007).

Given the above, the objectives of the present study were to evaluate the knowledge on blood transfusion of professionals of the nursing team of ICUs and to identify the factors associated with such knowledge.

\section{MATERIAL AND METHODS}

This is an observational, analytical, nonexperimental study with cross-sectional design and quantitative approach held in the adult ICU (general and coronary) of a general, large, public and teaching hospital located in the region of the Triângulo Mineiro, State of Minas Gerais. The study had financial support from the Foundation for Research of Minas Gerais (FAPEMIG).

The target population $(\mathrm{N})$ consisted of 73 professionals of the nursing team, corresponding to 10 nurses, 49 technicians and 14 assistants that provided direct assistance to customers and on all shifts of sectors included in the study. To calculate the sample size (n), a positive Pearson correlation coefficient $(r=0.4)$ between the training time and the scores of knowledge was considered, for a significance level of 0.05 and an error type II of 0.1 , resulting in an a priori power of $90 \%$. Using the application Power Analysis and Sample Size (PASS) version 2002, a minimum sample size of $n=61$ was reached.

The sample (n) of the study consisted of 64 professionals of the nursing team (nurses, technicians and assistants) who provided direct assistance in all shifts, had a formal employment relationship with the institution and were scheduled for service during the months of data collection. Nine $(12.3 \%)$ professionals were excluded, as shown in Figure 1.

\section{Professionals of the ICU nursing team $(\mathrm{N}=73)$}

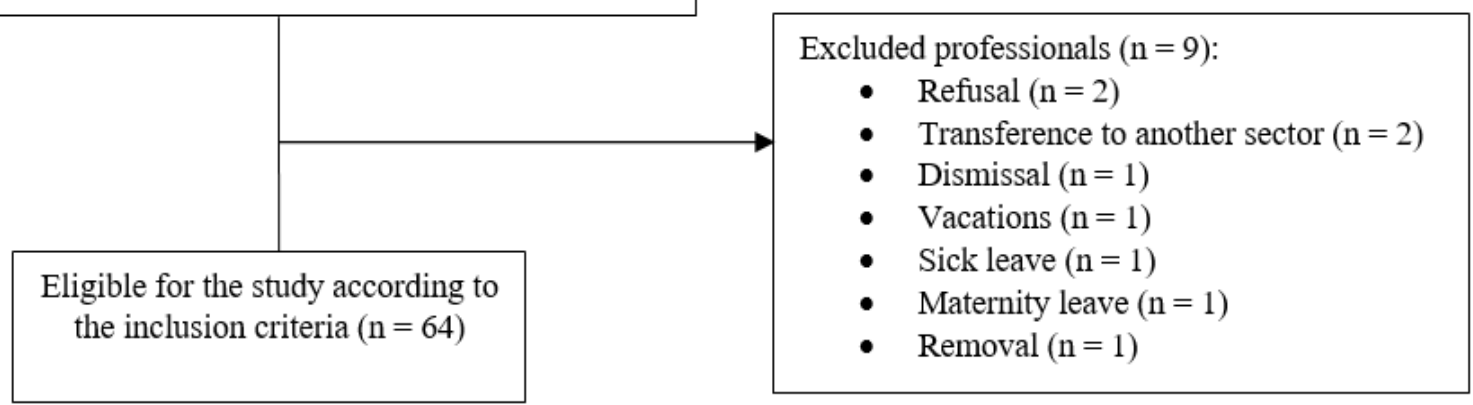

Figure 1. Diagram of the population and study sample. Minas Gerais, Brazil, 2015. ICU: Intensive Care Unit.

To collect the data, we used a validated instrument of the type check list (TAVARES et al., 2015) which contained questions related to professional and institutional aspects and on blood transfusion, subdivided into pre-transfusion step (PTS), transfusion step (TS) and post-transfusion step (POTS).

Study variables were: professional category; time after graduation; type of educational institution; time of experience in the profession, in the institution and in the sector; number of formal employments; participation in specific training on blood transfusion; participation in post-graduate courses; participation in training courses and scientific events; search for information in the literature/ clarification of doubts; adoption of any standard or guideline; feeling confident about carrying out the transfusion process; and score of knowledge about practices related to blood transfusion.

The Informed Consent was handed to professionals and after their signing, the instrument of data collection was given to them as well as the necessary instructions for filling it.

Data were entered into an Excel ${ }^{\circledR}$ spreadsheet of the program Windows $X P{ }^{\circledR}$ with by double entry for further validation. Data were then taken to the program Statistical Package for Social 
Sciences (SPSS) version 20.0 for processing and analysis.

Initially, univariate analysis was performed. Qualitative variables were analyzed using descriptive statistics, that is, the distribution of absolute and percentage frequency. Quantitative variables were described through measures of centrality (mean) and spread (standard deviation, minimum and maximum value). For bivariate analysis, contingency tables were built and contrasts of measures of central tendency between groups, defined by categorical variables, were performed.

In order to calculate the score of knowledge, a formula was used where the number of items correctly answered was divided by the total number of items and multiplied by one hundred.

The domains considered for the calculation of sub-score were PTS, TS and POTS.

$T$-tests were used to compare variables that had two categories and Pearson correlation tests were used for quantitative variables in order to check whether there was a correlation between qualitative variables (related to professional aspects, and to the hospital structure and environment) and the score of knowledge. Statistically significant associations were those with $\mathrm{p} \leq 0.05$; In Pearson correlation tests, relations were considered weak $(0$ $\leq|r|<0.3)$, moderate $(0.3 \leq|r|<0.5)$ or strong $(0.5 \leq|r|<1.6)$ (COHEN, 1988).

This study was conducted in compliance with the Resolution 466/2012 of the National Health Council (NHC), with the approval of the institution researched and the Ethics Committee of the Federal University of Triângulo Mineiro (CEP-UFTM) under Opinion 2.434/2013 . Anonymity was guaranteed for all participants, which were identified by a number.

\section{RESULTS}

The sample consisted of 64 professionals. Most were nursing technicians (73.4\%) and females (85.9\%).

The average age of professionals was 37.7 years, with a minimum of 22 and maximum of 58 years. Most got their training in public institutions $(54.7 \%)$, and the prevailing institutional bond was statutory (56.3\%), as shown in Table 1.

Table 1. Characterization of professionals of the nursing team, Uberaba, MG, Brazil, $2015(\mathrm{n}=64)$

\begin{tabular}{lc}
\hline Characteristics & $\mathbf{n}(\mathbf{\%})$ \\
\hline Gender & $55(85.9)$ \\
$\quad$ Female & $9(14.1)$ \\
$\quad$ Male & \\
Professional category & $8(12.5)$ \\
$\quad$ Nursing assistant & $47(73.4)$ \\
$\quad$ Nursing technician & $9(14.1)$ \\
$\quad$ Nurse & \\
Educational institution & $35(54.7)$ \\
$\quad$ Public & $29(45.3)$ \\
$\quad$ Private & \\
Institutional bond & $36(56.2)$ \\
$\quad$ Statutory & $28(43.8)$ \\
$\quad$ CLT & $\mathbf{6 4}(\mathbf{1 0 0})$ \\
\hline Total & \\
\hline
\end{tabular}

CLT - Consolidation of Labor Laws

With regard to employment, $87.5 \%$ had no other jobs. Among the professionals who had other employments, $7.8 \%$ had two bonds; $3.1 \%$ had three bonds; and $1.6 \%$ had four bonds.

Table 2 shows the average time after graduating, time of professional activity, time of work experience in the profession, in the institution and in the sector.

Regarding the work shift, $45.3 \%$ worked at night, $26.6 \%$ in the evening, $26.6 \%$ in the morning and $1.6 \%$ under conditions of 8 hours a day. On the unit of work, $50.0 \%$ reported working in the coronary ICU and $50.0 \%$ in the general ICU.

The average number of times that the professional said to carry out blood transfusion was 3.6 times/month, with a minimum of zero and a maximum of 40 times/month. 
Table 2. Professional characterization of the nursing team, Uberaba, MG, Brazil, 2015

\begin{tabular}{|c|c|c|c|c|c|}
\hline Time & $\begin{array}{c}\text { Mean } \\
\text { (months) }\end{array}$ & $\begin{array}{l}\text { Median } \\
\text { (months) }\end{array}$ & $\begin{array}{c}\text { SD } \\
\text { (months) }\end{array}$ & $\begin{array}{c}\text { Minimum } \\
\text { (months) }\end{array}$ & $\begin{array}{c}\text { Maximum } \\
\text { (months) }\end{array}$ \\
\hline Vocational training & 144.81 & 130.00 & 88.84 & 4.00 & 331.00 \\
\hline $\begin{array}{l}\text { Time of experience in the } \\
\text { profession }\end{array}$ & 138.84 & 119.50 & 94.32 & 9.00 & 399.00 \\
\hline $\begin{array}{l}\text { Time of experience in the } \\
\text { institution }\end{array}$ & 112.83 & 97.00 & 80.33 & 2.00 & 329.00 \\
\hline $\begin{array}{l}\text { Time of experience in the } \\
\text { unit }\end{array}$ & 77.64 & 70.00 & 57.21 & 1.00 & 220.00 \\
\hline
\end{tabular}

SD: Standard Deviation.

With regard to training and/or orientation of the institution to carry out blood transfusion, $93.8 \%$ of professionals said they received these; $62.5 \%$ of the professionals have participated in specific training programs; $34.4 \%$ have attended specific training courses; and $7.8 \%$ have participated in specific scientific events on blood transfusion. With regard to post-graduate degrees, $35.9 \%$ of the respondents reported having such degree, $35.9 \%$ reported specialization and $1.6 \%$ reported master's degree.

On the search for information in the literature, $76.6 \%$ of professionals said they sought information or to get their doubts about blood transfusion resolved. With regard to the rules adopted in transfusion practice, $78.1 \%$ reported to adopt the Standard Operating Procedure Manual (SOP) of the sector in their conduct; $3.1 \%$ adopt the ordinance 1353 of the Ministry of Health and SOP; $3.1 \%$ adopt the CBR 153 and Ordinance 1353 of the Ministry of Health; $3.1 \%$ adopt the Ordinance 1353 of the Ministry of Health; 3.1\% adopt the CBR 57 and the SOP; $1.6 \%$ adopted the CBR $57 ; 1.6 \%$ adopted all standards; and $6.3 \%$ did not adopt or knew rules or guidelines.

All professionals reported to feel confident while performing the transfusion process.

The average overall score of knowledge was $52.8 \%$, with a minimum of $26.0 \%$ and a maximum of $74.0 \%$. Table 3 shows the overall score and the scores in the three steps related to blood transfusion.

Table 3. Scores of knowledge related to blood transfusion, Uberaba, MG, Brazil, 2015

$$
(n=64)
$$

\begin{tabular}{lccccc}
\hline Frequency distribution & $\begin{array}{c}\text { Mean } \\
(\boldsymbol{\%})\end{array}$ & Median & SD & $\begin{array}{c}\text { Minimum } \\
(\boldsymbol{\%})\end{array}$ & $\begin{array}{c}\text { Maximum } \\
(\boldsymbol{\%})\end{array}$ \\
\hline Overall score & 52.8 & 54.3 & 10.4 & 26.0 & 74.0 \\
PTS Score & 50.7 & 57.1 & 15.7 & 0.0 & 86.0 \\
TS Score & 54.4 & 54.2 & 11.2 & 21.0 & 75.0 \\
POTS Score & 62.5 & 66.7 & 28.8 & 0.0 & 100.0 \\
\hline
\end{tabular}

SD: standard deviation; PTS: pre-transfusion step; TS: transfusion step; POTS: post-transfusion step.

There was statistically significant correlation between the professional category nurses $(\mathrm{p}=0.05)$ and the overall score, and marginally significant $(\mathrm{p}=0.068)$ between the professional category nurses and the score in TS.

Professionals with institutional bond of the type statutory had a better score in PTS $(\mathrm{p}=0.008)$. There was statistical significance between the variable "participation in specific training for blood transfusion" and POTS, between the variable "participation in specific course of professional improvement" and the score in the PTS, and between the variable "participation in post- graduation course" and the overall score in PTS (p $<0.05)$.

Table 4 shows the correlation between the scores of knowledge in transfusion steps and professional aspects. 
Table 4. Correlation between the overall score and the transfusion steps and professional aspects ( $t$-test), Uberaba, MG, Brazil, $2015(\mathrm{n}=64)$

\begin{tabular}{|c|c|c|c|c|c|c|c|c|}
\hline \multirow{2}{*}{ Characteristics } & \multicolumn{2}{|c|}{ General Score } & \multicolumn{2}{|c|}{ PTS Score } & \multicolumn{2}{|c|}{ TS Score } & \multicolumn{2}{|c|}{ POTS Score } \\
\hline & Mean & SD & Mean & SD & Mean & SD & Mean & SD \\
\hline \multicolumn{9}{|l|}{ Gender } \\
\hline Female & 53.09 & 10.77 & 50.65 & 16.45 & 54,85 & 11,28 & 62,42 & 28,73 \\
\hline Male & 50.79 & 7.92 & 50.79 & 10.38 & 51,39 & 10,62 & 62,96 & 30,93 \\
\hline p-value & \multicolumn{2}{|c|}{0.543} & \multicolumn{2}{|c|}{0.980} & \multicolumn{2}{|c|}{0.388} & \multicolumn{2}{|c|}{0.959} \\
\hline \multicolumn{9}{|l|}{$\begin{array}{l}\text { Professional } \\
\text { category }\end{array}$} \\
\hline $\begin{array}{l}\text { Nursing assistant } \\
\text { and technician }\end{array}$ & 51.74 & 10.40 & 49.61 & 15.76 & 53,33 & 11,32 & 61,21 & 29,93 \\
\hline Nurse & 59.05 & 8.33 & 57.14 & 14.29 & 60,65 & 8,10 & 70,37 & 20,03 \\
\hline p-value & \multicolumn{2}{|c|}{0.050} & \multicolumn{2}{|c|}{0.184} & \multicolumn{2}{|c|}{0.068} & \multicolumn{2}{|c|}{0.259} \\
\hline \multicolumn{9}{|l|}{$\begin{array}{l}\text { Type of institution of } \\
\text { training }\end{array}$} \\
\hline Public & 53.71 & 9.57 & 52.24 & 13.39 & 55,12 & 10,11 & 63,81 & 29,56 \\
\hline Private & 51.63 & 11.27 & 48.77 & 18.12 & 53,45 & 12,45 & 60,92 & 28,27 \\
\hline p-value & \multicolumn{2}{|c|}{0.428} & \multicolumn{2}{|c|}{0.381} & \multicolumn{2}{|c|}{0.556} & \multicolumn{2}{|c|}{0.693} \\
\hline \multicolumn{9}{|l|}{ Institutional bond } \\
\hline $\begin{array}{l}\text { Legal regime } \\
\text { Only one }\end{array}$ & \multicolumn{7}{|c|}{ Only one } & 29,98 \\
\hline CLL & 51.43 & 11.27 & 44.90 & 16.36 & 54,01 & 11,81 & 63,10 & 27,72 \\
\hline p-value & \multicolumn{2}{|c|}{0.368} & \multicolumn{2}{|c|}{0.008} & \multicolumn{2}{|c|}{0.830} & \multicolumn{2}{|c|}{0.885} \\
\hline Other employments & & & & & & & & \\
\hline Yes & 50.71 & 12.10 & 44.64 & 11.62 & 52,60 & 12,97 & 66,67 & 35,63 \\
\hline No & 53.06 & 10.22 & 51.03 & 16.04 & 54,61 & 11,00 & 61,90 & 28,02 \\
\hline p-value & 0.5 & & & & 0.6 & & 0.6 & \\
\hline $\begin{array}{l}\text { Received training or } \\
\text { guidelines }\end{array}$ & & & & & & & & \\
\hline Yes & 53.00 & 10.50 & 51.43 & 14.45 & 54,44 & 11,40 & 62,78 & 28,85 \\
\hline No & 49.29 & 9.15 & 39.29 & 29.45 & 53,13 & 7,89 & 58,33 & 31,91 \\
\hline p-value & 0.4 & & & & 0.8 & & 0.7 & \\
\hline $\begin{array}{l}\text { Participation in } \\
\text { specific training for } \\
\text { blood transfusion }\end{array}$ & & & & & & & & \\
\hline Yes & 54.43 & 9.42 & 52.86 & 12.19 & 55,31 & 10,59 & 69,17 & 26,57 \\
\hline No & 50.00 & 11.52 & 47.02 & 19.97 & 52,78 & 12,14 & 51,39 & 29,45 \\
\hline p-value & 0.0 & & & & 0.3 & & & \\
\hline $\begin{array}{l}\text { Participation of } \\
\text { specific } \\
\text { improvement course } \\
\text { for blood transfusion }\end{array}$ & & & & & & & & \\
\hline Yes & 54.55 & 10.69 & 55.84 & 14.56 & 54,92 & 11,69 & 66,67 & 27,22 \\
\hline No & 51.84 & 10.24 & 47.96 & 15.72 & 54,07 & 11,02 & 60,32 & 29,67 \\
\hline p-value & 0.3 & & & & & & & \\
\hline $\begin{array}{l}\text { Participation in } \\
\text { specific scientific } \\
\text { event for blood } \\
\text { transfusion }\end{array}$ & & & & & & & & \\
\hline Yes & 49.14 & 11.32 & 42.86 & 10.10 & 51,67 & 10,86 & 60,00 & 36,51 \\
\hline No & 53.08 & 10.36 & 51.33 & 15.94 & 54,59 & 11,26 & 62,71 & 28,42 \\
\hline $\begin{array}{c}\text { p-value } \\
\text { Post-graduation } \\
\text { degree }\end{array}$ & 0.4 & & & & & & & \\
\hline
\end{tabular}




\begin{tabular}{|c|c|c|c|c|c|c|c|c|}
\hline Yes & 56.27 & 9.57 & 57.76 & 14.59 & 57,43 & 10,20 & 62,32 & 30,66 \\
\hline No & 50.80 & 10.43 & 46.69 & 14.99 & 52,64 & 11,44 & 62,60 & 28,08 \\
\hline p-value & \multicolumn{2}{|c|}{0.042} & \multicolumn{2}{|c|}{0.006} & \multicolumn{2}{|c|}{0.100} & \multicolumn{2}{|c|}{0.971} \\
\hline
\end{tabular}

Search information in the literature/clarify doubts

$\begin{array}{ccccccccr}\text { Yes } & 53.06 & 11.02 & 51.90 & 14.78 & 54,25 & 11,55 & 63,95 & 28,74 \\ \text { No } & 51.81 & 8.28 & 46.67 & 18.28 & 54,72 & 10,19 & 57,78 & 29,46 \\ \text { p-value } & 0.687 & & 0.262 & 0.888 & 0.472\end{array}$

Adopt any standard and/or guideline

$\begin{array}{ccccccccc}\text { Yes } & 52.52 & 10.30 & 50.71 & 15.65 & 53,89 & 11,11 & 63,33 & 27,91 \\ \text { No } & 56.43 & 12.86 & 50.00 & 18.44 & 61,46 & 10,96 & 50,00 & 43,03 \\ \text { p-value } & 0.471 & & 0.931 & 0.192 & 0.374\end{array}$

Statistically significant values are in bold. PTS: pre-transfusion step; TS: transfusion step; POTS: post-transfusion step; SD: standard deviation: CLL: Consolidation of Labor Laws.

As for correlation with the numerical variables, the correlation between the variable "number of blood transfusions carried out in the month" with the overall score $(\mathrm{p}=0.077)$ and the TS step $(p=0.066)$ were marginally significant, and the variable "time of experience in the sector" and the score in the POTS $(\mathrm{p}=0.073)$ was also marginally significant. However, these correlations were characterized as weak $(0 \leq|\mathrm{r}|<0.3)$. The other variables showed no influence on the knowledge of professionals.

Table 5 shows the values of $r$ and $p$ for numeric variables.

Table 5. Correlation between the overall score and the transfusion steps and numeric variables (Pearson), Uberaba, MG, Brazil, $2015(\mathrm{n}=64)$

\begin{tabular}{|c|c|c|c|c|c|c|c|c|}
\hline \multirow[t]{2}{*}{ Characteristics } & \multicolumn{2}{|c|}{ Overall score } & \multicolumn{2}{|c|}{ PTS Score } & \multicolumn{2}{|c|}{ TS Score } & \multicolumn{2}{|c|}{ POTS Score } \\
\hline & $r$ & p-value & $r$ & $\begin{array}{c}\text { p- } \\
\text { value }\end{array}$ & $r$ & $\begin{array}{l}\text { p- } \\
\text { value }\end{array}$ & $r$ & $\begin{array}{l}\text { p- } \\
\text { value }\end{array}$ \\
\hline $\begin{array}{l}\text { Number of blood } \\
\text { transfusions } \\
\text { performed/month }\end{array}$ & 0.223 & 0.077 & 0.106 & 0.404 & 0.231 & 0.066 & 0.086 & 0.501 \\
\hline $\begin{array}{l}\text { Time after } \\
\text { graduation }\end{array}$ & 0.017 & 0.894 & 0.054 & 0.672 & 0.022 & 0.864 & -0.065 & 0.610 \\
\hline $\begin{array}{l}\text { Time of } \\
\text { experience in the } \\
\text { profession }\end{array}$ & 0.040 & 0.756 & 0.118 & 0.353 & 0.008 & 0.950 & -0.008 & 0.951 \\
\hline $\begin{array}{l}\text { Time of } \\
\text { experience in the } \\
\text { institution }\end{array}$ & 0.023 & 0.858 & 0.070 & 0.584 & 0.036 & 0.779 & -0.104 & 0.415 \\
\hline $\begin{array}{l}\text { Time of } \\
\text { experience in the } \\
\text { sector }\end{array}$ & -0.056 & 0.659 & 0.112 & 0.378 & -0.050 & 0.697 & -0.225 & 0.073 \\
\hline $\begin{array}{l}\text { Number of } \\
\text { participations in } \\
\text { specific training }\end{array}$ & -0.049 & 0.703 & -0.060 & 0.638 & -0.040 & 0.752 & -0.003 & 0.978 \\
\hline $\begin{array}{l}\text { Number of } \\
\text { employments }\end{array}$ & -0.001 & 0.996 & -0.181 & 0.152 & 0.040 & 0.753 & 0.103 & 0.418 \\
\hline
\end{tabular}

Statistically significant values are in bold. PTS: pre-transfusion step; TS: transfusion step; POTS: post-transfusion step 


\section{DISCUSSION}

The average age of professionals was 37.7 years, with a minimum of 22.0 and a maximum of 58.0 years, data similar to a research that shows predominance of the age between 21 and 55 years, averaging 36 years (HIJJI et al., 2013). Other studies show prevalence of the age group between 21 and 32 years (SILVA et al., 2009) and between 31 and 40 years (SILVA; SOMAVILLA, 2010).

Regarding gender, studies corroborate the results of the present research, with results ranging from 62.0 to $85.2 \%$ of female predominance (HIJJI; OWEIS; DABBOUR, 2012; SILVA; SOMAVILLA, 2010; SILVA et al., 2010).

A study conducted in a university hospital in Rio Grande do Norte showed that $81.5 \%$ of ICU professionals are nursing technicians and $18.5 \%$ are nurses, like in the present study (SILVA et al., 2009).

Concerning the educational institution, most received their training in public institutions (54.7\%). Research conducted in a University Hospital in Minas Gerais demonstrated that $63.0 \%$ of nursing technicians got their degree in private institutions and $60.0 \%$ of nurses, in public institution (SILVA; SOARES; IWAMOTO, 2009).

Regarding the time after graduation and professional experience, the average was 12 years; and the average time of work in the institution was nine years; and the average time in the unit of study was six years. Study in Paraná showed that $54.0 \%$ of professionals are graduated for seven to 10 years (BARBOSA; NICOLA, 2014). Another study identified an average of five to 10 years of experience in the institution (SILVA; SOMAVILLA, 2010). As for time of experience, the literature showed a time less than five years (66.0\%), and five years or less (68.0\%) (HIJJI et al., 2013; HIJI; OWEIS; DABBOUR, 2012). Regarding the time working in the unit, researches corroborate this data, since there are records of nursing technicians $(46.0 \%)$ with more than six years, and nurses $(60.0 \%)$ between one and five years (SILVA; SOARES; IWAMOTO, 2009).

A study performed in an ICU showed that $87.0 \%$ of nursing technicians and $100 \%$ of the nurses receive information about the transfusion practice. Regarding training and professional development, $60.0 \%$ of nurses say they have participated in training or guidance received within the institution (SILVA; SOARES; IWAMOTO, 2009).

However, opposite records are also available: Hijji, Oweis and Dabbour (2012) carried out a study in which $92.4 \%$ of nurses say they have never received training on blood transfusion and $33 \%$ reported the need for training on applying blood. Another survey revealed that $85 \%$ of nurses had never received training on blood transfusion, and $14 \%$ reported the need for specific training for performing this procedure (HIJJI et al., 2013).

As for the number of times the professional says to perform blood transfusions, a study conducted in ICUs in hospitals of Jordan of showed that during the six months preceding the data collection, $89.0 \%$ of nurses had applied blood transfusions from one to four times, and eventually 12 times/month, what corroborates the data from the present study (HIJJI; OWEIS; DABBOUR, 2012). On the other hand, a Brazilian study showed that the nursing staff (63.0\%) perform blood transfusions weekly (BARBOSA; NICOLA, 2014).

Regarding the titration and postgraduate courses, $80.0 \%$ of nurses had attended post-graduate courses (SILVA et al., 2009). On the other hand, another study showed that $4 \%$ of nurses have master's degree (HIJJI; OWEIS; DABBOUR, 2012). These figures are higher than those found in the present study.

In this study, all professionals reported to feel confident when performing the transfusion procedure. However, the literature shows that 33\% of professionals say they feel confident regarding the conduct to be taken in case of a transfusion reaction; $46 \%$ report having confidence only in some times, and $21 \%$ report not feeling confident in making a decision before a reaction (BARBOSA; NICOLA, 2014).

Concerning the evaluation of knowledge about blood transfusion, the average overall score was $52.7 \%$. A study conducted in hospitals of the Emirate of Abu Dhabi confirmed the lack of knowledge of nurses about blood transfusion, ranging from 27.0 to $56.0 \%$, and none of the professionals answered correctly to all questions (HIJJI et al., 2013).

In PTS, issues on prescription and request of transfusion of blood or blood components, and the collection of blood samples for pre-transfusion and identification tests were addressed. The minimum knowledge score was zero and the highest, $86.0 \%$. Silva et al. found inadequate procedures of PTS, such as the collection of the sample (91.7\%), prescription of transfusion (84.0\%), the application form of transfusion (66.7\%), the identification of the bag $(84.0 \%)$, the identification of the patient $(82.0 \%)$ and the identification of tubes $(69.6 \%)$ (SILVA et al., 2010). A study conducted in ICUs of hospitals in Jordan demonstrated that only $2.0 \%$ of 
the professionals are aware of all the steps that must be followed to correctly identify a patient in the PTS (HIJJI; OWEIS; DABBOUR, 2012).

There is a major flaw in this step that precedes the blood transfusion, that is, in the sample identification. An incompatible ABO system compromises the safety of the patient, causing serious transfusion reactions that may lead the client to death. Qualified and trained professionals can prevent this mistake from happening (SILVA et al., 2010).

The step related to the act of transfusion (TS) showed minimal knowledge score of $21.0 \%$ and a maximum of $75.0 \%$. In TS, a study showed that $92.0 \%$ of professionals reported to wrap the blood bags in a blanket, leave it at room temperature, dip in hot water or place it in a microwave oven (HIJJI; OWEIS; DABBOUR, 2012). Other misconducts are related to the administration of medications concomitant to the transfusion $(46.0 \%)$, observation of the patient $(30.0 \%)$ and the use of specific equipo $(8.0 \%)$, besides the identification of blood components and conference with the identification in medical records. Notably, $18.0 \%$ of professionals do not carry out these actions correctly (SILVA et al., 2010).

The POTS, related to the immediate transfusion complications, had a higher average score $(62.50 \%)$ compared to the other stages, showing that professionals had a greater knowledge regarding transfusion reactions, with early detection of signs and symptoms, and about the nursing care to be provided. The immediate transfusion reaction is defined as one that occurs within 24 hours after initiation of the procedure. The patient must receive immediate care; the institution shall disclose in the records all actions taken and conducts adopted, ensuring care and notifying the adverse event (BRASIL, 2016).

Research showed that $67 \%$ of professionals recognize sometimes signs and symptoms that are indicative of transfusion reactions while $25 \%$ do not recognize (BARBOSA; NICOLA, 2014). There is still record of inadequacy regarding the care with a transfusion reaction (85.2\%) (SILVA et al., 2009).

According to the bivariate analysis, the professional category "nurse" showed statistical significance for the overall score, demonstrating greater knowledge in relation to other professional categories. The literature shows the importance of nurses in the practice of transfusion because their are in the lead of their team, organizing and supervising the care. It is necessary, therefore, to constantly search for updates regarding this practice.
Indeed, the transfusion process is complex and brings risks to the patient if not done properly (BARBOSA; NICOLA, 2014).

According to the bivariate analysis, the professionals who had participated in specific trainings in blood transfusion had higher knowledge score only in relation to POTS, suggesting the need for investment in training within the hospital units addressing all stages of the transfusion process, especially the care with the PTS and the transfusion act. Training consists of short-term courses. The results showed how the training is important and really make a difference in the transfusion therapy, identifying how training improves the practice, creating greater efficiency and a professional with more knowledge (BARBOSA; NICOLA, 2014).

Few professionals had participated in the specific improvement courses for blood transfusion, which are longer than trainings. Professionals, however, had higher knowledge scores regarding the PTS. Participation in post-graduate courses demonstrated that professionals with higher qualification had higher knowledge in the overall score regarding the PTS. Study on the program of nursing education in Brazil (undergraduate and graduate) says that these types of education have an important position, and the main objective is to train and qualify professionals to meet the demands of the health sector, which are each day more and more complex and to the reach of goals to increase the construction of relevant and innovative knowledge (ERDMANN; FERNANDES; TEIXEIRA, 2011)

In this study, according to bivariate analysis, the number of transfusions was statistically significant for the overall score in TS. This shows that the greater the number of transfusions carried out by professionals, the greater their knowledge, especially with regard to the application of blood or the administration of the therapy. In contrast, professional ignorance concerning PTS and the immediate transfusion complications (POTS) interferes with the quality of the process and with the patient safety. Nearly half of professionals $(46.0 \%)$ reported that they "sometimes" feel confident on the procedures adopted because of a transfusion reaction. This make misconduct possible and this compromises the safety of the patient, endangering the life of the patient (BARBOSA; NICOLA, 2014).

The time of experience in the sector showed, according to bivariate analysis, that those who have been working for longer times in the sector have higher knowledge score only in POTS. As the ICU is a sector where blood transfusion is a routine, due to the clinical severity of the situation 
of hospitalized patients, it was expected that more time in the sector would lead professionals to show relevant knowledge scores at all stages of the transfusion process.

As limitation of this study and considering the method used, there was no monitoring of the blood transfusions management process, but this did not compromise the achievement of objectives. It is suggested to carry out prospective studies in the area, including the systematic observation of transfusion practice, with a view to safety and quality of the whole process.

\section{CONCLUSIONS}

The deficiency in the knowledge of professionals in relation to transfusion therapy. Regarding the stages of the transfusion process, knowledge was higher in the post-transfusion step, showing that the team is more prepared to manage with transfusion complications than to prevent them.
Factors associated with knowledge about blood transfusion were: professional category nurse, participation in training and specific courses for professional improvement, post-graduate degree, number of blood transfusions carried out per month and time working in the sector.

The importance to increase the oportunities to acquire skills such as training courses and continuing and permanent education for nursing professionals who work in critical care units is reinforced, focusing on patient safety and quality of care.

\section{ACKNOWLEDGEMENTS}

The authors thank the Foundation for Research of the State of Minas Gerais (FAPEMIG) and the National Council for Scientific and Technological Development (CNPq) for financial support.

RESUMO: Este estudo teve como objetivo avaliar o conhecimento dos profissionais da equipe de enfermagem de unidade de terapia intensiva sobre hemotransfusão e identificar os fatores associados a tal conhecimento. Estudo observacional, analítico, não experimental, transversal, realizado nas unidades de terapia intensiva adulto de um hospital público, de ensino e grande porte, localizado em Minas Gerais. Para a coleta de dados, utilizou-se um instrumento validado, do tipo checklist. Realizaram-se análise descritiva, cálculo de escores de conhecimento, teste $t$ e correlação de Pearson. Participaram deste estudo 64 profissionais da equipe de enfermagem, sendo 73,4\% técnicos em enfermagem, e $85,9 \%$ do sexo feminino. A média de idade foi 37,7 anos. Afirmaram ter recebido treinamento sobre hemotransfusão 93,8\% dos profissionais; 76,6\% referiram que procuravam se informar sobre o tema; e $100 \%$ referiram se sentir seguros durante a execução do procedimento. A média do escore geral de conhecimento foi de $52,8 \%$. Os fatores associados ao conhecimento sobre hemotransfusão foram: categoria profissional enfermeiro, participação em capacitação e curso de aperfeiçoamento específico, possuir pós-graduação, número de hemotransfusões administradas por mês e tempo de atuação no setor. Evidenciou-se uma deficiência no conhecimento dos profissionais em relação à terapêutica transfusional. Isso reforça a necessidade de incrementar a oferta de capacitações, cursos de aperfeiçoamento, e educação continuada e permanente aos profissionais de enfermagem que atuam nas unidades críticas, tendo como foco a segurança do paciente $\mathrm{e}$ a qualidade do cuidado.

PALAVRAS-CHAVE: Conhecimento. Equipe de enfermagem. Unidades de terapia intensiva. Transfusão de sangue.

\section{REFERENCES}

BARBOSA, H. B.; NICOLA, A. L. Enfermagem na terapia transfusional e hemovigilância: análise da conformidade em um hospital de ensino. Revista Saúde, Santa Maria, v. 40, n. 2, p. 97-104, 2014. Disponível em: http://cascavel.ufsm.br/revistas/ojs-2.2.2/index.php/revistasaude/article/view/13074/pdf. Acesso em 04 abr. 2016.

BARBOSA, S. M.; TORRES, C. A.; GUBERT, F. A.; PINHEIRO, P. N.; VIEIRA, N. F. Enfermagem e a prática hemoterápica no Brasil: revisão integrativa. Acta Paul Enferm., São Paulo, v. 24, n. 1, p. 132-6, 2011. Disponível em: http://www.scielo.br/pdf/ape/v24n1/v24n1a20.pdf. Acesso em 04 abr. 2016. 
BRASIL. Ministério da Saúde. Portaria no 158, 04/02/2016. Brasília: Ministério da Saúde, 2016. Disponível em: http://www.hemoce.ce.gov.br/images/PDF/portaria\%20gm-ms\%20n158-2016.pdf. Acesso em 13 mai. 2016.

Agência Nacional de Vigilância Sanitária (ANVISA). Resolução da Diretoria Colegiada - RDC 34 de 11 de junho de 2014. Brasília: ANVISA, 2014.

BAYRAKTAR, N.; ERDIL, F. Blood transfusion knowledge and practice among nurses in Turkey. J Intraven Nurs., United States, v. 23, n. 5, p. 310-7, sept/oct. 2000.

COHEN, J. Statistical power analysis for the behavioral sciences. 2 ed. Mahwah: Lawrence Earlbaum; 1988. CORWIN, H. L.; GETTINGER, A.; PEARL, R. G.; FINK, M. P.; LEVY, M. M.; ABRAHAM, E.;

MACLNTYRE, N. R.; SHABOT, M. M.; DUH, M. S.; SHAPIRO, M. J. The CRIT Study: Anemia and blood transfusion in the critically ill-current clinical practice in the United States. Crit Care Med., New York, v. 32, n. 1, p. 39-52, jan. 2004.

COSTA FILHO, R. C.; GUTIERREZ, F.; FERNANDES, H.; MENDES, C.; LOBO, S. Transfusão de hemácias em terapia intensiva: controvérsias entre evidências. Rev. bras. ter. intensiva, São Paulo, v. 21, n. 3, p. 31523, 2009.

ERDMANN, A. L.; FERNANDES, J. D.; TEIXEIRA, G. A. Panorama da educação em enfermagem no Brasil: graduação e pós-graduação. Enfermagem em Foco. v. 2, p. 89-93, 2011. Disponível em: http://revista.portalcofen.gov.br/index.php/enfermagem/article/view/91/76. Acesso em 10 abr. 2016.

FERREIRA, O.; MARTINEZ, E. Z.; MOTA, C. A.; SILVA, A. M. Avaliação do conhecimento sobre hemoterapia e segurança transfusional de profissionais de enfermagem. Rev. Bras. Hematol. Hemoter., São José do Rio Preto, v. 29, n. 2, p. 160-7, jun. 2007. Disponível em: http://www.scielo.br/scielo.php?script=sci_arttext\&pid=S1516-84842007000200015\&lng=en\&nrm=iso. Acesso em 02 fev. 2016.

HIJJI, B.; PARAHOO, K.; HUSSEIN, M. M.; BARR, O. Knowledge of blood transfusion among nurses. J Clin Nurs., England, v. 22, n. 17-18, p. 2536-50, sep. 2013.

HIJJI, B. M.; OWEIS, A. E.; DABBOUR, R. S. Measuring knowledge of blood transfusion: a survey of Jordanian nurses. Am Int J Contemp Res., v. 2, n. 10, p. 77-9, oct. 2012. Disponível em http://www.aijcrnet.com/journals/Vol_2_No_10_October_2012/10.pdf. Acesso em 04 fev. 2016.

SAILLOUR-GLÉNISSON, F.; TRICAUD, S.; MATHLOULIN, S.; BOUCHON, B.; GALPÉRINE, I.; FIALON, P.; SALMI, L. R. Factors associated with nurses poor Knowledge and practice of transfusion safety procedures in Aquitaine, France. Int J Qual Health Care. England, v. 14, n. 1, p. 25-32, feb. 2002.

SELLU, D. H.; DAVIS, R. E.; VICENT, C. A. Assessment of blood administration competencies using objective structured clinical examination. Transfus Med., England, v. 22, n. 6. p. 409-17, dec. 2012.

SERIOUS HAZARDS OF TRANSFUSION (SHOT). Annual Report 2007. Manchester, 2008. Disponível em: http://www.shotuk.org/wp-content/uploads/2010/03/SHOT-Report-2007.pdf. Acesso em 04 abr. 2016.

SILVA, L. A.; SOMAVILLA, M. B. Conhecimentos da equipe de enfermagem sobre terapia transfusional. Cogitare Enferm. Curitiba, v. 15, n. 2, p. 327-33, abr./jun. 2010. Disponível em: http://revistas.ufpr.br/cogitare/article/viewFile/17871/11661. Acesso em 04 fev. 2016.

SILVA, K. F. N.; SOARES, S.; IWAMOTO, H. H. A prática transfusional e a formação dos profissionais de saúde. Rev. Bras. Hematol. Hemoter., São Paulo, v. 31, n. 6, p. 421-6, 2009. Disponível em: http://www.scielo.br/scielo.php?script=sci_arttext\&pid=S1516-84842009000600009\&lng=en\&nrm=iso. Acesso em 19 abr. 2016. 
SILVA, M. A.; TORRES, G. V.; MELO, G. S.; COSTA, I. K.; TIBURCIO, M. P.; FARIAS, T. Y. Conhecimento acerca do processo transfusional da equipe de enfermagem da UTI de um Hospital Universitário. Ciência, Cuidado e Saúde, Maringá, v. 8, n. 4, p. 571-8, 2009. Disponível em: http://periodicos.uem.br/ojs/index.php/CiencCuidSaude/article/view/9676/5389. Acesso em 04 sbr. 2016.

SILVA, M. A.; TORRES, G. V.; COSTA, I. K.; TIBURCIO, M. P.; MELO, G. S.; DIAS, Y. A. Condutas assistenciais dos profissionais de enfermagem de uma unidade de terapia intensiva durante o processo transfusional. Rev Enferm UFPE on line, Recife, v. 4, n. 1, p. 181-90, jan. 2010.

TAVARES, J. L.; BARICHELLO, E.; MATTIA, A. L.; BARBOSA, M. H. Fatores associados ao conhecimento da equipe de enfermagem de um hospital de ensino sobre hemotransfusão. Rev Latino-Am Enfermagem, Ribeirão Preto, v. 23, n. 4, p. 595-602, jul./ago. 2015. Disponível em:

http://www.scielo.br/pdf/rlae/v23n4/pt_0104-1169-rlae-23-04-00595.pdf. Acesso em 04 abr. 2016. 